\title{
An investigation on role of customer relationship management (CRM) in increasing organizational effectiveness
}

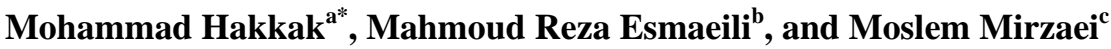

\begin{tabular}{l}
\hline A R T I C L E I N F O \\
\hline Article history: \\
Received August 15, 2012 \\
Received in revised format \\
25 September 2012 \\
Accepted 1 October 2012 \\
Available online \\
October 42012 \\
\hline Keywords: \\
Effectiveness \\
Models of organizational \\
effectiveness \\
Customer relationship \\
management \\
Customer relationship \\
management dimensions
\end{tabular}

${ }^{a}$ Assistant Professor, Management Department, Lorestan University, Khoram Abad, Iran ${ }^{b}$ Assistant Professor, Management Department, Lorestan University, Khoram Abad, Iran ${ }^{c} M A$ in Management, Lorestan University, Khoram Abad, Iran A B S T R A C T

This paper investigates the role of customer relationship management (CRM) in improving organizational effectiveness. The proposed model of this paper is implemented on customers of one of Iranian banks called Keshavarzi (Agriculture). In this research a questionnaire was prepared and 150 customers as sample were selected randomly. The results of the survey have been validated using Cronbach alpha, which was 0.926 . Research hypotheses are analyzed using Pearson's correlation test and all hypotheses are confirmed when the level of significance was five percent. The results of our survey have disclosed that all these mentioned factors could impact customer satisfaction, positively. In addition, we have also considered Freedman test to rank the relative importance of these factors, results indicate that customer-centered was the first priority followed by recognizing customers' need, Mutual understanding and Loyalty. Customer complaints are also the last priority in the ranking.

(C) 2012 Growing Science Ltd. All rights reserved.

\section{Introduction}

Organizational effectiveness is an important process, which is studied by organizational researchers. Besides, the definition and concept of efficacy is ambiguous and there are different description on organizational effectiveness. Despite the fact that there are many attempts to explain the concept organizational effectiveness, there have been little success to provide a unique commonly accepted concept (Wesley, 2008). On the other hand, customer focus and attention to customer service is not a new concept. It is certainly a business dynamic recognized for a long time by more people than the management. Thus, achieving the full potential of each customer relationship should be the major goal of every business (Boxwell, 2000).

* Corresponding author. + 989122599727

E-mail addresses: md_hakkak@yahoo.com (M. Hakkak) 
To survive in the global markets, focusing on the customer is a key factor for small and medium enterprises (SMEs). It is known that it takes up to five times more money to acquire a new customer than to get an existing customer to make a new purchase (Baumeister, 2002).

\section{Statement of Problem}

Effectiveness in recent years has become very prominent concept because of global competition, organizations' manage to hang on and the main focus on competition comprehensive organizational focused on production and productivity (Scott \& Gerald, 2006). According to Cameron and Whetten (1983) it is important to understand the idea of productivity management and it is difficult to imagine a theory of organizational without meaning organizational effectiveness. Organizational effectiveness is essential for success in Economy (Mani, 2011).

Many organizations have found they cannot be determined with a net profit of the company's effectiveness (Daft, 1377). CRM is one of the factors that can affect the effectiveness. In today's business world, the relationship with the customer is at the center of attention. Today, organizations put their customers at the heart of all their activities and their sales and marketing strategies are based on their review (RastegarMoghadam, 2010). There is no doubt that the most important assets of most organizations are their customers (Faghihi \& Mousavi, 2010). Customer satisfaction is important because many studies have shown that customer satisfaction has a positive effect on the profitability of the organization (Harkiranpal, 2006).

This study measures the effectiveness of the organization in a case study from banking industry. A list of Stakeholders of the institution and examples of criteria are evaluated based on the effectiveness of the institution (Robbins, 1999), which are summarized as follows,

\begin{tabular}{ll}
\hline Stakeholder & Effectiveness indicators \\
\hline Company owners & Financial returns \\
Employees & Employee satisfaction, salaries and bonuses \\
Customers & Satisfaction of the quality and services \\
Creditors & The amount of credit \\
Society & Role company in improving society \\
Suppliers of raw materials & Satisfactorily transaction \\
Government & Compliance with laws and regulations \\
\hline
\end{tabular}

This research considers the effectiveness of their customers' views and the customer satisfaction index to measure.

\section{Importance and necessity of research}

There are many studies focused on some of the CRM components, such as the relationship between customer satisfaction and business performance, the relationship between loyalty and profitability, and so on. Therefore, the severe shortages in research have been on the strategic focus and have a wider organization (Mehrabi, 2008). In early studies, CRM has been as a fundamental reconstruction of marketing disciplines and it used to be derived as part of new marketing logic (Day, 2004). Nowadays, continuous development and after sales service with long-term relationship with customers have also been considered, significantly (Abbasi \& Turkmen, 2010). Customer attraction and retention for many organizations have become major challenges. Thus, a growing number of organizations using CRM systems have been on (Keramati et al., 2008). CRM presents an overall picture and makes it possible to have a special relationship with every client (Keramati \& Nikzad, 2008). CRM allows us to have a clear picture and this allows to build a special relationship with each customer (Keramati \& Nikzad, 2008). Panel Gary is a part of CRM which includes all tasks such as marketing, manufacturing, customer service, sales circular, and circular services needed to 
communicate with the customer directly or indirectly (Gray \& Byun, 2001). Recent research shows that in the field of marketing, attention and focus on CRM can enhance organizational performance (Jabbari, 2009). Better understanding of customers' needs will enable us to serve them better and to keep them forever (Khalid, et al., 2011).

\section{The research objectives}

The main objective of the research to establish the relationship between CRM and an increase the organization's effectiveness based on strategic decision-making. The proposed study is accomplished on one of Iranian banks named Agriculture. In line with this objective, the following objectives are pursued:

1. Recognizing CRM needs in different branches of Agricultural Bank

2. Recognizing mutual understanding with customers in different branches of Agricultural Bank

3. Understanding the Component customer's central agricultural bank branches

4. Understanding of the Component loyalty in the branches of agricultural Bank

5. Understanding the Component customer complaint in the branches of agricultural Bank

\section{Research hypotheses}

The main hypotheses and subsidiary hypotheses are as follows,

The main hypothesis: CRM is effective in increasing organizational effectiveness.

Sub hypothesis 1: There is a relationship between recognizing the need and increase in the effectiveness of the bank.

Sub hypothesis 2: There is a relationship between mutual understanding and increase in the effectiveness of the Bank.

Sub-hypothesis 3: There is a relationship between the customer orientation and increase in the effectiveness of the bank.

Sub-hypothesis 4: There is a relationship between the customer loyalty and increase in the effectiveness of the Bank.

Sub-Hypothesis 5: There is a relationship between customer complaints and increase in the effectiveness of the Bank.

\section{A literature review}

An organization is a planned social unit deliberately structured for the purpose of attaining specific goals (Parsons, 1960). Etzioni (1975) identified three broad characteristics of organizations, including (1) nonrandom and planned divisions of labor, power, and communication responsibilities to support the achievement of specific goals; (2) the presence of one or more power centers (i.e., dominant coalitions) that direct the concerted efforts of the organization toward its goals; and (3) the substitution of personnel whereby unsatisfactory members can be removed and others assigned their tasks (Etzioni, 1975). 
Management specialists, agents for achieving organizational efficiency have also been considered. According to Taylor (1878), effectiveness through factors such as maximizing production, minimizing costs and benefits of applying the desired range, may be achievable. According to Fayvl (1925), the efficiency results from exercising discipline within the organization as transparent operations (Najaf Beigi, 2000). Cameron knows the effectiveness of the organization's situation where the organization limited amount of resources consumed (Cameron, 1979). Organizations must take care of environmental affairs, properly (Hodge \&Anthony,1988; Mohammadzadeh \& Mhrvzhan, 1996).

\subsection{Historical overview of effectiveness models}

\section{Approaches Ideal types}

In this approach "rational-legal" form of organization was characterized by decisions based on rules, equal treatment for all employees, separation of the position from its occupant, staffing and promotions based on skills and expertise, specific work standards, and documented work performance (Cameron \& Whetten, 1996).

\section{Contingency Approaches}

This perspective argued that effectiveness was not a function of the extent in which an organization reflected the qualities of an ideal profile, but instead, it depends on the match between an organization's profile and environmental conditions (Cameron \& Whetten,1996).

\section{Multiple Constituencies}

In this approach, effective organizations are viewed as those which had accurate information about the expectations of strategically critical constituents and adapted internal organizational activities, goals, and values to match those expectations (Cameron \& Whetten, 1996).

\section{Paradox Model}

This model recognizes the inherently paradoxical nature of organizational functioning. From this point of view, effective organizations are both short and long-term focused, flexible and rigid, centralized and decentralized, goal and resource control oriented, concerned about the needs of members and the demands of customers (Cameron \& Whetten, 1996).

\subsection{Models of organizational effectiveness}

Looking back over the past three decades, there have been at least three major evolutionary shifts in the prevailing views of organizational effectiveness. They are summarized in Table 1.

Table 1

Evolution of different approaches on organizational effectiveness

\begin{tabular}{llll}
\hline Approach & Authors & Basic Approach & Common Models \\
\hline Ideal Types & $\begin{array}{l}\text { Weber; Barnard: } \\
\text { price }\end{array}$ & Matching the organization's profile and the ideal type & $\begin{array}{l}\text { Goal models Internal } \\
\text { process models }\end{array}$ \\
\hline $\begin{array}{l}\text { Contingency } \\
\text { Theory }\end{array}$ & Burns \& Stalker & $\begin{array}{l}\text { Matching the organization's profile and the } \\
\text { environmental conditions }\end{array}$ & System resource \\
\hline $\begin{array}{l}\text { Multiple } \\
\text { constituencies }\end{array}$ & Pfeffer \& Salancik & $\begin{array}{l}\text { Matching the organization's activities and the } \\
\text { constituencies expectations }\end{array}$ & $\begin{array}{l}\text { Strategic constituency } \\
\text { models }\end{array}$ \\
\hline $\begin{array}{l}\text { Paradox } \\
\text { Approach }\end{array}$ & Quinn \& Cameron & $\begin{array}{l}\text { Combining contradictory elements and managing } \\
\text { inconsistent expectations }\end{array}$ & $\begin{array}{l}\text { Competing values } \\
\text { model }\end{array}$ \\
\hline
\end{tabular}




\section{Goal Model}

In general, the goal model defines effectiveness as a complete or at least partial realization of the organization's goals (Etzioni, 1975). Early proponents of the goal-oriented approach for evaluating organizational effectiveness focused on outcomes or the ends resulting from the organization's activities. The goal-achievement model presumes that organizations are rational, deliberate, and goal seeking. It also incorporates a number of presuppositions, the most fundamental being that organizational goals exist (Wesley, 2008).

\section{Systems Model}

One advantage of the systems model's focus on balance and sustainability is its broader perspective. Rather than simply determine whether goals were achieved. The systems approach tends to look longer term and drive efficiencies within the organization that lead to growth and survival of the existing system (Wesley, 2008).

\section{Process Model}

This model is strong emphasis on internal processes and operations of the organization. The process model does not specify criteria for effectiveness; instead, it focuses on the process of becoming effective (Wesley, 2008).

\section{Strategic Constituencies Model}

In an effort to recognize various perspectives and values held by multiple organizational participants, the strategic constituencies model emerged. According to the strategic constituencies model, an effective organization is the one that satisfies the demands of its constituencies (Wesley, 2008).

\section{Competing Values Framework}

The competing values framework (CVF) includes two fundamental premises: (1) there are multiple and conflicting criteria associated with assessing organizational effectiveness, and (2) multiple constituencies will give preference to certain values that differ according to their organizational perspective and the interests they represent (Wesley,2008). Quinn and Rohrbaugh (1983) initially developed the CVF to clarify the language used in defining the organizational effectiveness construct in analysis, development, and design.

\subsection{Customer Relationship Management}

Increasing competition and decreasing customer loyalty have led to the emergence of concepts that focus on the nurturing of relationships to customers. Therefore, there is a major change in the way companies organize themselves, as businesses switch from product based to customer-based structures. A key driver of this change is the advent of CRM, which is underpinned by information and communication technologies (Ryals \& Knox, 2001).

Day and Van Den Bulte (2002) defined CRM as a cross-functional process for achieving a continuing dialogue with customers, across all their contact and access points, with personalized treatment of the most valuable customers, to increase customer retention and the effectiveness of marketing initiatives. CRM is the set of methodologies and tools that help an enterprise manage customer relationships in an organized way (Lawson-Body \& Limayem, 2004).

CRM consists of three (3) main components; customer relations, and management (Gray \& Byun, 2001). 


\section{Methodology}

The purpose of this study is to survey the role of CRM to increase the effectiveness of the organization. The study population consists of agricultural bank customers in city of Khorram Abad located in province of Lorestan, Iran. Sample size is 150 and cluster random sampling method is implemented. The data collection instrument was a questionnaire on the basis of Likert type. Reliability of the questionnaire using Cronbach's alpha is $92.6 \%$. Fig. 1 shows the structure of the proposed model.

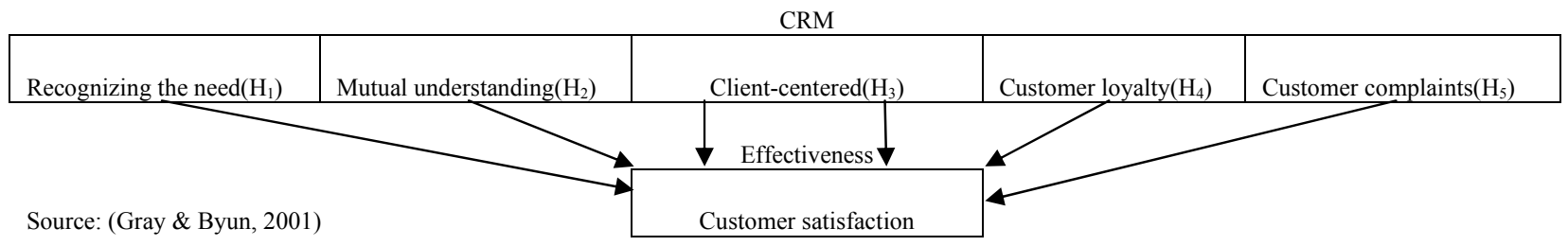

Fig. 1. The framework of the proposed model

\section{Research Findings}

\subsection{Demographic findings}

In our survey, $68 \%$ of the participants were male and the remaining $32 \%$ were female and in terms of their marital status, $42.7 \%$ were single and the remaining $57.2 \%$ were married.

\subsection{The results of testing all hypotheses}

The main hypothesis of this research is to understand whether CRM is effective in increasing organizational effectiveness. To test this hypothesis, and all hypotheses were converted to statistical assumptions:

$\mathrm{H}_{0}: \rho=0$

$\mathrm{H}_{1}: \rho \neq 0$

$\rho$ : Correlation coefficient between CRM and organizational effectiveness

\section{Table 2}

The results of correlation coefficient main hypothesis

\begin{tabular}{cccc}
\hline Correlation coefficient & Error level $(\alpha)$ & Significant level (P-Values) & Test Results \\
\hline 0.788 & 0.05 & 0.000 & $\mathrm{H}_{1}$ approved \\
\hline
\end{tabular}

As we can observe from the results of Table 2, the results are meaningful when the level of significant is five percent. Other test research hypotheses are described in Table 3.

Table 3

The results of correlation coefficient Research hypotheses

\begin{tabular}{llll}
\hline Hypothesis & correlation coefficient & (P-Values) & Results Test \\
\hline First & 0.574 & 0.000 & $\mathrm{H}_{1}$ approved \\
Second & 0.647 & 0.000 & $\mathrm{H}_{1}$ approved \\
Third & 0.739 & 0.000 & $\mathrm{H}_{1}$ approved \\
Fourth & 0.519 & 0.000 & $\mathrm{H}_{1}$ approved \\
Fifth & 0.767 & 0.000 & $\mathrm{H}_{1}$ approved \\
\hline
\end{tabular}

\subsection{Hypothesis test rankings}

We have used Friedman test to examine the views of respondents in the order of their relative importance. The chi-square test was computed for each five hypotheses and as we can observe from the results of Table 4, they are meaningful when the level of significance is five percent. 


\section{Table 4}

Ranked hypothesis Research according to their importance in increasing the effectiveness of Organization

\begin{tabular}{c|ccc}
\hline Priority & Hypothesis & Average Rating \\
\hline 1 & The customer-centered is effective in increasing the effectiveness organization. & 3.62 \\
2 & Recognizing customers' need is effective in increasing the effectiveness of the organization. & 3.53 & 3.31 \\
3 & Mutual understanding is effective in increasing the effectiveness of the organization. & 3.03 & 1.51 \\
\hline & Loyalty is effective in increasing the effectiveness of the organization. & \\
\hline
\end{tabular}

\section{Conclusion}

In this paper, we have investigated the role of customer relationship management on increasing organizational efficiency. The proposed study of this paper has considered five different hypotheses to understand the effects of different factors on organizational success. We have used Pearson correlation test to examine the relationship between recognizing the need, mutual understanding, client-centered, customer loyalty and customer complaints with customer satisfaction. The results of our survey have disclosed that all these mentioned factors could impact customer satisfaction, positively. In addition, we have also considered used Freedman test to rank the relative importance of these factors and customer-centered was number one priority followed by recognizing customers' need, Mutual understanding and Loyalty. Customer complaints are also the last priority in our ranking. The results of our results are consistent with Duiu and Halmajan (2007), Reinartz et al. (2004) and Chen et al. (2004).

\section{References}

Abbasi, M.R, \& Turkmen, M. (2010). Theoretical model of customer relationship management (CRM). Quarterly Business Review, 41, 4-5.

Baumeister, H. (2002).Customer relationship management for SME's. Institutfur Informatik, LMU, Oettingenstr. 67, D-80538 Munchen, Germany, 1-7.

Boxwell, L. (2000). Customer relationship management: Project A. 87701899 February.

Cameron, K. (1979). Evaluating Organizational Effectiveness in organized Anarchies. presented in Meeting of the Academy of Management

Cameron, K. S., \& Whetten, D. A. (1983). Organizational effectiveness: A comparison of multiple model. New York: Academic Press

Cameron, K. S., \& Whetten, D. A. (1996). Organization effectiveness and quality: the second generation. Reprinted from higher education: handbook of theory and research, Agathon press, New York

Chen, J., Russell, Ching, K.H., Eldon, Y., \& Li, Yiling Liao (2004). An exploratory study of the effects of CRM practices on CRM effectiveness and business performance. Fourth International Conference on Electronic Business (ICEB2004) / Beijing

Daft, R. L. (1999). Leadership : Theory and practice. Orlando, FL : The Dryden.

Day, G. S. (2004). Achieving Advantage with a New Dominant Logic. Journal of Marketing, 68 (January), 18-19.

Day, G.S., \& VandenBulte, C. (2002). Superiority in customer relationship management: consequences for competitive advantage and performance. The Wharton school, university of Pennsylvania, 1-49.

Etzioni, A. (1975). A comparative analysis of complex organizations (Rev. ed.). New York: Free Press

Faghihi, A., \& Mousavi, Z. (2010). Efficiency measurement model (effectiveness and efficiency) in the Iranian government services. Journal of Public Management, 2(4). 
Gray, P., \& Byun, J. (2001). Customer Relationship Management: Practical Tips for successful Implementation

Harkiranpal, S. (2006). The importance of customer satisfaction in relation to customer loyalty and retention. Asia Pacific University

Hodge, B. J., \& Anthony, W. P. (1988). Organization Theory. $3^{\text {rd }}$ ed., London, Allyn \& Bacon Inc

Jabbari, R. (2009). Provide a framework for evaluating the performance of customer relationship management (CRM).Unpublished master's thesis, Tehran University

Keramati, A., mshky, H., \& Nazari, S. (2010). Identifying risk factors and the priority ranking of project implementation, Customer relationship management in Iran. Journal of Business Research, 5. [In Persian].

Keramati, M. A., \& Nikzad, M. (2009). Evaluation of the key success factors in customer relationship management strategy of textile industry (with a phased approach). Journal of Textile Science and Technology, 4(1).

Khalid, R.,Haslina, M., Huda I.( 2011). Customer Relationship Management (CRM) Processes from Theory to Practice: The Pre-implementation Plan of CRM System. International Journal of e-Education, e-Business, e Management and e-Learning, 1.

Lawson-Body, A., \& Limayem, M. (2004). The impact of customer relationship management on customer loyalty: The moderating role of website characteristics. Journal of ComputerMediated Communication, 9(4), http://www.ascusc.org/jcmc.

Mani,L. R. S.( 2011). Organization Effectiveness in Management Education Institutions. ICOQM.

Mehrabi, H. (2008). Model for assessing the impact of customer relationship management (CRM) on performance of companies and organizations, Unpublished master's thesis, Tehran University

Mohammadzadeh, A., \& Mhrvzhan, A. (1996). Contingency view of organizational behavior. Tehran: Publications Allameh Tabatabaei, First edition

Najaf Beigi, R. (2000). Organization and Management. Tehran: Center for Scientific Publications, Islamic Azad University

Parsons, T. (1960). Structure and process in modern societies Glencoe. IL: The Free Press.

Quinn, R. E., \& Rohrbaugh, J. (1983). A spatial model of effectiveness criteria: Towards a competing values approach to organizational analysis. Management Science, 29, 363-377

RastegarMoghadam, A. (2010). Identify and investigate factors to improve customer relationship management in the Islamic Republic of Iran Airlines (Homa) with a process approach, Unpublished master's thesis, Tehran University

Reinartz, W.,Krafft, M., \& Hoyer, W.D. (2004). The Customer Relationship Management Process: Its Measurement and Impact on Performance. Journal of Marketing Research, 41, 293-305.

Robbins, S. P., \& Barnwell, N. (1998). Organisation Theory: Concepts and cases. New York, Sydney : Prentice Hall

Ryals, L., \& Knox, S. (2001). Cross-functional issues in the implementation of relationship marketing through customer relationship management. European Management Journal, 19(5), 534-542.

Scott, R, W., \& Gerald, F, D. (2006). Organization and organizing: Rational, Natural and. Open Systems Perspectives. Prentice and Hall.

Wesley A, Martz (2008). Evaluating organizational effectiveness. A Dissertation Submitted to the Faculty of the Graduate College in partial fulfillment of the requirements for the Degree of Doctor of Philosophy, Western Michigan University Kalamazoo. 